\title{
KEEFEKTIVAN EKSTRAK BIOTA LAUT AGLAOPHENIA TERHADAP AKTIVITAS ENZIM EKSTRASELULER DAN KANDUNGAN PROTEIN FUSARIUM SERTA PERSENTASE BUSUK BATANG VANILI
}

\author{
I Ketut Suada \\ Jurusan Agroekoteknologi Fakultas Pertanian Universitas Udayana Jalan PB. Sudirman Denpasar 80232. \\ E-mail: ketutsuada@yahoo.com
}

\begin{abstract}
Effectiveness of Aglaophenia marine biota extract against activity of extracellular enzymes, protein content of Fusarium, and percentage of vanilla stem rot. The aim of this research was to investigate the effect of Aglaophenia extract on the activity of cellulase and pectinase, protein content of Fusarium, and percentage of vanilla stem rot. This reasearch was carried out in-vitro with concentration of extract of 2000, 1000, 500, 250, 125, 63, and 0 ppm (w/v). The treatments were also applied on vanilla plant to determine their effect on the stem rot incidence. The results exhibited that the higher the concentration of the extract given, both enzymes activity and mycelial protein content of Fusarium decreased. The decrease of enzymes activity resulted in the decrease of vanilla stem rot percentage. The effectiveness of the extract to suppress stem rot was higher than mancozeb, therefore, the extract could be used as a control agent against vanilla stem rot.
\end{abstract}

Key words: cellulase, pectinase, Aglaophenia, stem rot.

\begin{abstract}
ABSTRAK
Keefektivan ekstrak biota laut Aglaophenia terhadap aktivitas enzim ekstraseluler dan kandungan protein Fusarium serta persentase busuk batang vanili. Tujuan penelitian ini adalah untuk mengetahui pengaruh ekstrak Aglaophenia terhadap aktivitas enzim selulase dan pektinase, kandungan protein Fusarium, dan persentase busuk batang vanili. Penelitian pengaruh ekstrak Aglaophenia ini dilakukan secara in-vitro yang terdiri dari konsentrasi 2000, 1000, 500, 250, 125, 63, dan 0 ppm (w/v). Perlakuan juga diberikan pada tanaman vanili untuk menentukan pengaruh konsentrasi ekstrak terhadap persentase busuk batang vanili. Hasil penelitian menunjukkan bahwa makin tinggi konsentrasi ekstrak yang diberikan, makin rendah aktivitas kedua enzim yang diteliti dan demikian pula makin rendah persentase busuk batang vanili. Menurunnya aktivitas enzim akibat pemberian ekstrak Aglaophenia menyebabkan menurunnya persentase busuk batang. Keefektivan ekstrak tersebut lebih tinggi dibanding fungisida mancozeb, oleh karena itu ekstrak tersebut dapat digunakan sebagai agen pengendali busuk batang vanili.
\end{abstract}

Kata kunci: selulase, pektinase, Aglaophenia, busuk batang.

\section{PENDAHULUAN}

Pada saat suatu patogen nekrotrofik menyerang tanaman maka patogen tersebut mula-mula akan menghadapi kutikula, dinding sel, dan kemudian sistem kimiawi pertahanan tanaman. Dinding sel merupakan hambatan yang sangat kompleks karena terdiri dari berbagai molekul polimer dengan ikatan kimia yang berbeda-beda, namun komponen utama dinding sel tanaman adalah selulose dan pektin (Onuh \& Ohazurike, 2008). Oleh karena itu agar dapat menginfeksi sel tanaman, patogen memerlukan berbagai jenis enzim untuk memecah dinding sel tersebut (Dickinson, 2003).

Enzim poligalakturonase dan selulase adalah enzim yang masing-masing dapat mengubah pektin dan selulosa. Enzim tersebut merupakan pendegradasi dinding sel yang pertama kali terbentuk pada jamur (deVries \& Visser, 2001), bakteri, dan nematoda pada saat organisme tersebut menyerang inangnya (Mahalingam et al., 1999).

Poligalakturonase yang merupakan enzim endopoligalakturonase memecah cincin poligalakturonan secara acak pada tanaman menjadi rantai-rantai pendek berupa oligogalakturonan. Sementara eksopoligalakturonase bekerja di ujung (terminal) dari cincin poligalakturonan dan menghasilkan produk monomer seperti asam-asam galakturonan (Bateman \& Basham, 1976). Menurut Scott et al. (2005), terdapat bukti dengan korelasi kuat adanya keterlibatan endopoligalakturonase dalam menyebabkan gejala penyakit dengan karakteristik busuk lunak. 
Produksi enzim pektolitik dan selulolitik, agen utama patogenisitas organisme, telah diidentifikasi pada beberapa spesies Pythium, termasuk $P$. aphanedermatum (Sutton et al., 2006) dan $P$. debaryanum (Wood \& Gupta, 1958 dalam Onuh \& Ohazurike, 2008). Sekresi poligalakturonase merupakan salah satu syarat kunci untuk terjadinya infeksi pada tanaman (Clausen \& Reen, 1996) dan bahkan perbedaan tingkat sekresinya dan kecepatan tumbuh miselia jamur patogen secara signifikan berkorelasi dengan tingkat virulensi (Wei-Chen et al., 1998; Ohazurike \& Arinze, 1999; Owen-Going et al., 2004). Mutasi terhadap gen yang mengekspresikan enzim pektat liase pada Erwinia spp. menyebabkan patogenisitas patogen tersebut sangat menurun (Dickinson, 2003). Berbagai jenis Fusarium telah diketahui mampu menghasilkan enzim selulase dan pektinase selama proses infeksi pada sel tanaman. Menurut Ugwuanyi \& Obeta (1997), Fusarium oxysporum dalam media pektin dapat menghasilkan enzim pendegradasi pektin seperti hidrolase, liase, dan pektinesterase.

Kelompok enzim pektinolitik memegang peranan penting dalam proses maserasi dinding sel dengan mendegradasi pektin pada lamela tengah sel pada dinding sel primer sehingga sel-sel tanaman menjadi terpisah satu sama lainnya (Bruhlmann et al., 1994; Onuh \& Ohazurike, 2008). Proses hidrolisis itu dimulai dengan esterifikasi pektin oleh enzim pektin metil esterase menjadi metanol dan asam poligalakturonat (Reignault et al., 2008).

Secara molekuler, keefektivan suatu fungisida atau ekstrak tertentu dapat pula ditentukan dengan melihat produktivitas protein jamur sasaran. Protein akan terganggu produksinya jika jamur dikenai metabolit sekunder seperti fenol (senyawa umum yang dihasilkan oleh organisme antagonis/antibiosis) karena senyawa tersebut menghambat aktivitas beberapa enzim. Enzim yang segera terganggu aktivitasnya adalah glukosa-6fosfat dehidrogenase serta suksinat dehidrogenase yang merupakan enzim yang berperan dalam respirasi (Dickinson, 2003).

Untuk menekan perkembangan penyakit tumbuhan khususnya jamur, berbagai jenis fungisida telah diterapkan. Fungisida sintetik berangsur-angsur ditinggalkan dan penelitian ke arah penemuan fungsida organik terus dikembangkan. Bahan dari biota laut mulai pula banyak diungkap karena telah dibuktikan bahwa sumber daya laut Indonesia sangat besar dan belum digali dengan sungguh-sungguh. Untuk megetahui keefektivan ekstrak hewan laut Aglaophenia terhadap Fusarium, dapat diketahui melalui pengaruhnya terhadap produktivitas protein dan aktivitas enzim patogen di samping pengaruhnya terhadap tingkat serangan. Penelitian ini dimaksudkan untuk mengetahui potensi hewan laut Aglaophenia sp. dalam upaya penanggulangan penyakit vanili.

\section{METODE PENELITIAN}

Tempat dan Waktu. Penelitian ini dilakukan di Laboratorium Bioteknologi Fakultas Pertanian Universitas Udayana. Sampel hewan laut Aglaophenia sp. diambil dari pantai Tukad Abu Karangasem Bali. Penelitian ini dilakukan mulai bulan Oktober 2008 sampai Februari 2009.

Isolasi Fusarium oxysporum. Fusarium yang digunakan, diisolasi dari batang vanili yang bergejala busuk batang dengan menggunakan media Matuo (tiap liter mengandung $1,00 \mathrm{~g} \mathrm{~K}_{2} \mathrm{PO}_{4} 0,50 \mathrm{~g} \mathrm{KCl}, 0,50 \mathrm{~g}$ $\mathrm{MgSO}_{4} .7 \mathrm{H}_{2} \mathrm{O}, 0,01 \mathrm{~g} \mathrm{Fe}-\mathrm{Na}-E D T A, 2,00 \mathrm{~g} \mathrm{~L}-$ Asparagine, 20,00 g D-Galaktose, 1,00 liter akuades) yang khusus untuk mengisolasi Fusarium (Matuo, 1972). Sterilisasi bagian bergejala dilakukan dengan menggunakan alkohol $70 \%$ selama 1 menit, kemudian dibilas dengan akuades steril. Melalui subkultur, biakan murni yang diperoleh diisolasi berdasarkan spora tunggal untuk memperoleh genetik jamur yang seragam.

Pembuatan Ekstrak Hewan Laut. Hasil skrining yang dilakukan terhadap 53 jenis biota laut menunjukkan bahwa hewan laut Aglaophenia sp. (Filum Cnidaria, Kelas Hydrozoa, Famili Plumularidae, Genus Aglaophenia) sangat efektif menekan Fusarium secara in-vitro. Ekstrak metanolnya dapat menimbulkan zona hambat diameter $58 \mathrm{~mm}$ dan nilai MIC (minimum inhibition concentration) $0,05 \%$ (tidak dipublikasikan). Jasad hewan laut tersebut dengan kadar air $12,5 \%$ yang telah digiling halus digunakan dalam penelitian ini. Sebanyak $500 \mathrm{~g}$ serbuk dimaserasi dengan metanol $1 \mathrm{~L}$ dan dikocok dengan kecepatan 25 rpm selama 24 jam. Setelah disaring dengan kertas Whatman no. 2, filtrat ditampung dan residunya dimaserasi ulang sebanyak dua kali. Filtrat gabungan dipekatkan dengan penguap vakum berputar pada $40^{\circ} \mathrm{C}$ sampai diperoleh ekstrak kasar. Ekstrak kasar ini dikeringdinginkan, kemudian disimpan dalam botol berwarna gelap dan siap digunakan dalam percobaan.

Pembuatan Ekstrak Enzim dan Bahan Analisis Protein. Sebanyak $30 \mathrm{~mL}$ PDB (potato dextrose broth) pH 4,5 dalam tabung Erlenmeyer ditambah ekstrak Aglaophenia sp. sesuai konsentrasi uji. Tiap tabung diinokulasi satu potongan koloni jamur Fusarium 
diamater $5 \mathrm{~mm}$ umur lima hari, kemudian diinkubasi selama tujuh hari pada $28^{\circ} \mathrm{C}$ dengan pengocokan pada $125 \mathrm{rpm}$. Setelah masa inkubasi, biakan disaring dengan kertas Whatman no. 2 sehingga diperoleh filtrat sebagai ekstrak enzim. Miselia yang diperoleh digunakan untuk bahan analisis protein.

Pengukuran Aktivitas Selulase. Aktivitas enzim ini ditentukan dengan metode DNS (3,5-dinitrosalicylic acid) (Wu et al., 2008). Campuran reaksi terdiri dari $0,1 \mathrm{~mL}$ ekstrak enzim, $1,9 \mathrm{~mL} 1 \%$ (w/v) CMC-Na (Carboxymethylcellulose) dalam bufer fosfat, diinkubasi pada $50^{\circ} \mathrm{C}$ selama 20 menit. Sebanyak 1,5 mL DNS ditambahkan ke dalam campuran dan diaduk merata. Campuran tersebut dipanaskan $100^{\circ} \mathrm{C}$ selama 10 menit kemudian didinginkan. Spektrum gula reduksi diukur pada $\lambda 520 \mathrm{~nm}$. Satu unit aktivitas enzim adalah jumlah gula reduksi yang dihasilkan oleh $1 \mathrm{mg}$ enzim per menit pada kondisi uji. Glukosa (Sigma, St. Louise, Mo., USA) digunakan untuk membuat kurva standar.

Aktivitas Pektinase. Aktivitas pektinase (poligalakturonase) ditentukan mengikuti metode DNS (Wu et al., 2008). Campuran reaksi terdiri dari $2 \mathrm{~mL}$ ekstrak enzim, $2 \mathrm{~mL}$ larutan 0,4\% (w/v) pektin (polyD-galacturonic acid ethyl ester, Sigma Aldrich) dilarutkan dalam $0,2 \mathrm{M}$ bufer etil asetat $\mathrm{pH} 4,4$ dan diaduk merata. Campuran direaksikan pada suhu $45^{\circ} \mathrm{C}$ selama 30 menit, ditambahi 1,5 mL DNS dan dididihkan 5 menit. Spektrum gula reduksi diukur pada $\lambda 520 \mathrm{~nm}$. Standar kurva dibuat dari $0,1 \%(\mathrm{w} / \mathrm{v})$ asam $\beta$-galakturonat (Sigma, St. Louise, Mo., USA) dalam bufer etil asetat. Satu unit aktivitas enzim didefinisikan sebagai jumlah asam $\beta$-galakturonat dihasilkan dari hidrolisis pektin oleh $1 \mathrm{mg}$ enzim per menit pada kondisi uji.

Pembuatan Reagen DNS. Penentuan gula reduksi dilakukan dengan menggunakan reagen DNS. Reagen ini dibuat dari 0,2 $\mathrm{g}$ DNS, 0,04 $\mathrm{g}$ fenol, 0,01 $\mathrm{g} \mathrm{Na}_{2} \mathrm{SO}_{4}, 4$ g potassium sodium (+)-tartrat tetrahidrat (Rochelle salt) yang dilarutkan dalam $100 \mathrm{~mL}$ air (Wu et al., 2008). Kurva standar dibuat dari campuran $0,5 \mathrm{~mL}$ larutan glukosa (konsentrasi 0-800 $\mu \mathrm{g} / \mathrm{mL}$ ), 1,5 $\mathrm{mL}$ reagen DNS, dididihkan 5 menit dan absorbansinya diukur pada $\lambda 540$ $\mathrm{nm}$.

Pengukuran Protein dengan Metode Lowry. Sebagian miselia dari siapan di atas dioven pada suhu $80^{\circ} \mathrm{C}$ sampai berat konstan, lalu digerus sampai menjadi tepung. Sebanyak $25 \mathrm{mg}$ tepung tersebut ditambah dengan $1 \mathrm{~mL} 2 \mathrm{~N}$ natrium hidroksida, $\mathrm{pH} 7$, dikocok, lalu dipanaskan pada $80^{\circ} \mathrm{C}$ selama 10 menit. Campuran tersebut disentrifugasi pada $5000 \mathrm{rpm}$ selama 10 menit dan absorban supernatan diukur pada $\lambda 750 \mathrm{~nm}$. Kurva standar dibuat dari albumin serum Bovin (BSA) konsentrasi 0-100 $\mu \mathrm{g} / 100 \mu \mathrm{L}$ dalam natrium hidroksida.

Metode Bradford. Sebanyak $100 \mathrm{~g}$ miselia (berat basah) digerus setelah ditambah dengan nitrogen cair. Gerusan tersebut ditambah $0,5 \mathrm{~mL}$ bufer $(0,1 \mathrm{M}$ Tris$\mathrm{HClpH} 8,0$ dan $1 \mathrm{mM}$ EDTA), disentrifugasi pada 12.000 rpm selama 10 menit, kemudian supernatannya diencerkan dengan bufer yang sama (1:5). Sebanyak $20 \mu \mathrm{L}$ sampel tersebut ditambah dengan $1 \mathrm{~mL} 1 / 5$ reagen Bradford, dihomogenkan dengan vorteks, dan absorbansinya diukur pada $\lambda 595 \mathrm{~nm}$ setelah diinkubasi selama 30 menit. Kurva standar dibuat dengan albumin serum Bovin pada kondisi uji.

Ekstraksi Protein. Sebanyak $50 \mathrm{mg}$ tepung miselia ditambah dengan $500 \mu \mathrm{L}$ bufer ekstraksi yang terdiri dari: $20 \mathrm{mM}$ Tris, $10 \mathrm{mM}$ natrium bikarbonat, $10 \mathrm{mM}$ magnesium klorida, $0,1 \mathrm{mM} \mathrm{Na} \mathrm{NaDTA}_{2} 2 \mathrm{H}_{2} \mathrm{O}, 10 \mathrm{mM}$ â-mercaptoetanol, $100 \mathrm{gL}^{-1}$ sukrosa, dan $1 \mathrm{~mol} \mathrm{~L}^{-1}$ Triton $\mathrm{X}-100$ dalam $\mathrm{pH} 8(\mathrm{HCl})$. Ekstrak tersebut disentrifugasi pada $20.000 \mathrm{rpm}$ selama 20 menit pada $4^{\circ} \mathrm{C}$ dan supernatan yang terbentuk dipindahkan ke dalam eppendorf baru.

Pemisahan Protein. Protein dipisahkan dengan elektroforesis gel poliakrilamida pada alat elektroforesis (10x8 cm; SE 250, Höefer Scientific Instruments). Stacking gel terdiri dari $3,75 \%$ acryl amidebisacrylamide 30:0,8 v/v dalam $125 \mathrm{mM}$ bufer Tris/ $\mathrm{HCl} \mathrm{pH}$ 6,8 dan separating gel terdiri dari 7,5\% acryl amide-bisacrylamide 30:0,8 v/v dalam $375 \mathrm{mM}$ Tris/ $\mathrm{HCl}, \mathrm{pH} 8,8$ sebagai bufer. Gel dialiri listrik AC $110 \mathrm{~V}$, $15 \mathrm{~mA} 75$ menit dalam bufer elektroda Tris glycine mengandung $25 \mathrm{mM}$ Tris dan $192 \mathrm{mM}$ glicyne $\mathrm{pH} 8,3$.

Uji Aktivitas Ekstrak terhadap Persentase Busuk Batang Vanili. Pengujian ini menggunakan rancangan acak lengkap (RAL) faktorial dengan dua faktor yaitu konsentrasi ekstrak Aglaophenia sp. termasuk pembanding fungisida Mancozeb dan sumber inokulum yaitu tanah endemik dan tanah steril yang diinokulasi konidia Fusarium. Unit perlakuan diulang tiga kali dan tiap ulangan terdiri dari 10 stek tanaman.

Media tanam (tanah:pupuk kandang:pasir 2:1:1) sebanyak $2 \mathrm{~kg}$ dimasukkan ke dalam pot berdiamter 20 $\mathrm{cm}$ dan tinggi $30 \mathrm{~cm}$. Media tanam tersebut disiram dengan ekstrak Aglaophenia sp. sesuai perlakuan dengan volume $100 \%$ kapasitas lapang. Perlakuan yang sama diberikan pada tanah steril, namun pencampuran 
inokulum dilakukan dengan patogen kultur pada media beras (beras yang dikukus setengah matang diinokulasi patogen secara aseptik dan diinkubasi selama dua minggu). Jumlah inokulum akhir pada media tanam dibuat $10 \times 10^{5} \mathrm{CFU} / \mathrm{g}$ tanah media. Persentase serangan penyakit (busuk batang) dan jumlah inokulum Fusarium dalam tanah ditentukan setelah stek pada kontrol busuk semua. Jumlah inokulum ditentukan dengan metode cawan tuang (Hadiutomo, 1982). Sebanyak $1 \mathrm{~g}$ media tanam diencerkan $10^{5}$ kali dengan akuades steril kemudian diinkubasi pada media khusus Matuo selama tiga hari. Jumlah inokulum dihitung dengan mengalikan jumlah koloni yang tumbuh dengan faktor pengenceran. Data dianalisis ragam dan perbedaan pengaruh di antara perlakuan diuji dengan uji jarak berganda Duncan pada taraf $5 \%$.

\section{HASIL DAN PEMBAHASAN}

\section{Aktivitas Enzim Ekstraseluler (Selulase dan Pektinase) Fusarium. Ekstrak Aglaophenia sp.} mampu menurunkan aktivitas kedua enzim yang dikaji, yaitu selulase dan pektinase. Makin tinggi konsentrasi ekstrak yang diberikan, makin rendah aktivitas enzim tersebut. Enzim selulase lebih mudah terpengaruh dibanding pektinase, yaitu aktivitas selulase telah menurun pada konsentrasi ekstrak terendah (16 ppm) yang diberikan, sedangkan pektinase baru terpengaruh pada 250 ppm ekstrak (Tabel 1). Mudahnya enzim selulase terpengaruh oleh ekstrak dibandingkan pektinase mungkin berkaitan dengan struktur molekul enzim selulase yang berbeda dengan pektinase. Hal ini belum dapat dikaji karena molekul aktif ekstrak belum dapat diidentifikasi. Gambar 1 menunjukkan kurva regresi hubungan aktivitas kedua enzim dan konsentrasi ekstrak dengan koefisien determinasi kurva cukup tinggi yaitu 80\% dan 91\%. Angka tersebut menunjukkan ekstrak kasar tersebut sangat mempengaruhi aktivitas kedua enzim ekstraseluler Fusarium.

Mengingat kedua enzim tersebut paling berperan bagi patogenisitas suatu patogen (deVries \& Visser, 2001; Dickinson, 2003), maka adanya ekstrak Aglaophenia tersebut diduga dapat menyebabkan patogenisitas Fusarium berkurang secara nyata. Hal itu berarti ekstrak tersebut dapat berperan sebagai fungisida untuk menekan Fusarium penyebab busuk pada tanaman vanili.

\section{Pengaruh Ekstrak Aglaophenia terhadap Kandungan Protein Miselium Fusarium. Ekstrak} Aglaophenia sp. berpengaruh nyata terhadap kandungan protein jamur Fusarium. Makin tinggi konsentrasi ekstrak yang diberikan, makin rendah kandungan protein jamur (Tabel 2). Berdasarkan metoda Lowry, kadar protein miselium telah terpengaruh oleh 125 ppm ekstrak, sedangkan berdasarkan metode Bradford pengaruh itu terlihat pada konsentrasi ekstrak 500 ppm. Tertekannya protein tersebut didukung oleh penelitian Sudana (1997) yang menemukan bahwa berbagai senyawa metabolit sekunder dapat menekan sintesis asam nukleat dan protein Ceratocystis paradoxa. Hal tersebut disebabkan oleh terhambatnya aktivitas enzim glukosa-6-fosfat dehidrogenase serta suksinat dehidrogenase sehingga respirasi menurun. Menurut Bruinenberg (1982 dalam Sudana, 1997) dan (Dickinson, 2003) kedua enzim tersebut memegang peranan penting dalam berlangsungnya proses respirasi jamur.

Tabel 1. Aktivitas enzim ekstraseluler Fusarium yang diperlakukan dengan ekstrak Aglaophenia sp.

\begin{tabular}{|c|c|c|c|c|}
\hline \multirow{2}{*}{$\begin{array}{l}\text { Konsentrasi ekstrak } \\
(\mathrm{ppm})\end{array}$} & \multicolumn{4}{|c|}{ Aktivitas enzim ( $\mu \mathrm{g} / \mathrm{mL} / \mathrm{menit})$} \\
\hline & Selulase & & Pektinase & \\
\hline 0 & 1946,74 & $\mathrm{a}$ & 3930,89 & a \\
\hline 16 & 1908,86 & $\mathrm{~b}$ & 3914,23 & $\mathrm{a}$ \\
\hline 31 & 1885,38 & $\mathrm{~b}$ & 3908,17 & $\mathrm{a}$ \\
\hline 63 & 1817,20 & $\mathrm{c}$ & 3891,50 & a \\
\hline 125 & 1806,59 & $\mathrm{c}$ & 3806,65 & $\mathrm{a}$ \\
\hline 250 & 183,87 & $\mathrm{~d}$ & 389,98 & $\mathrm{~b}$ \\
\hline 500 & 166,44 & $\mathrm{~d}$ & 361,20 & $\mathrm{~b}$ \\
\hline 1000 & 164,92 & $\mathrm{~d}$ & 358,17 & $\mathrm{~b}$ \\
\hline 2000 & 0,00 & $\mathrm{e}$ & 0,00 & $\mathrm{c}$ \\
\hline
\end{tabular}

Angka-angka (rata-rata dari tiga ulangan) pada kolom yang sama yang diikuti oleh huruf yang sama tidak berbeda berdasarkan uji jarak berganda Duncan $(p>0,05)$. 


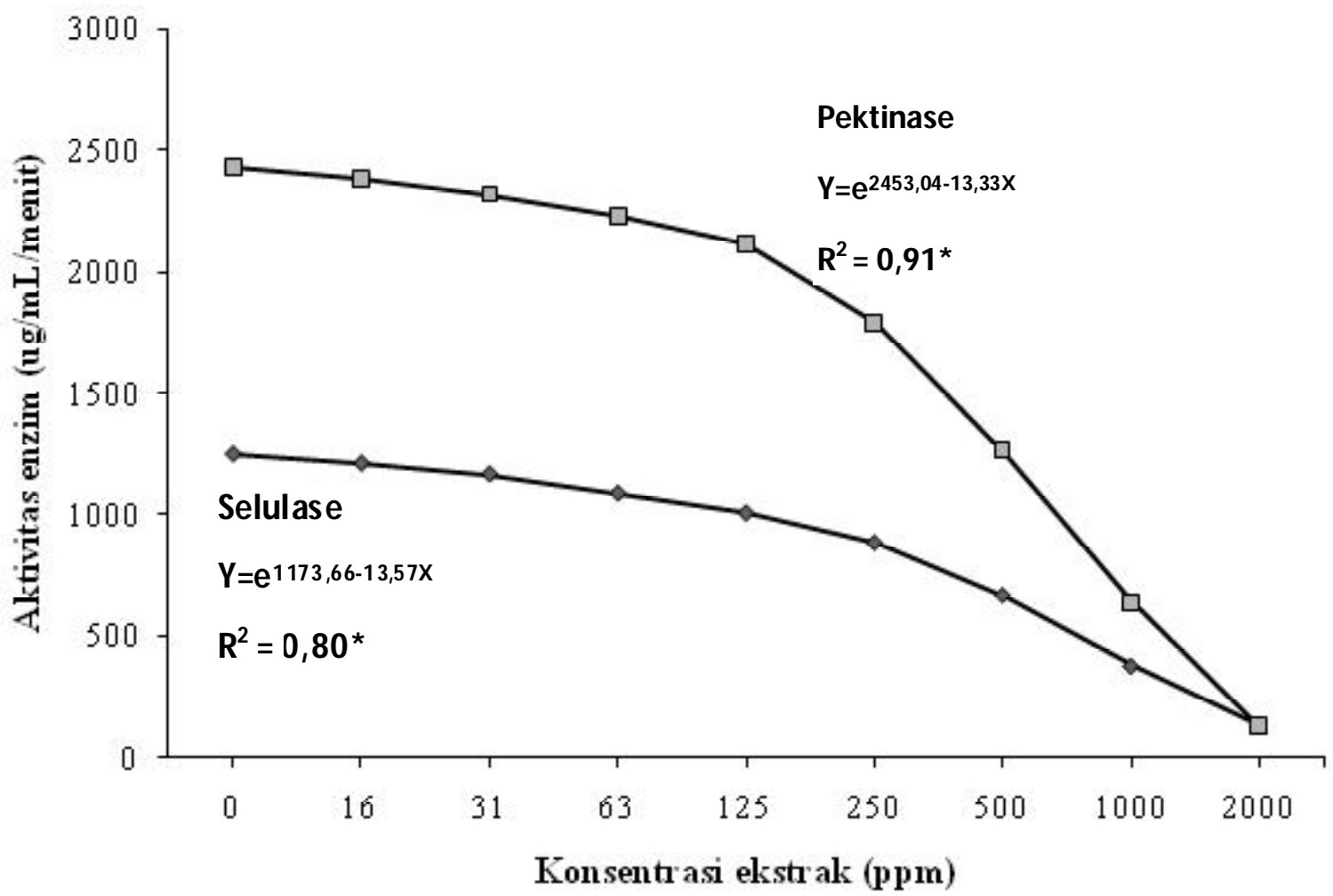

Gambar 1. Hubungan antara konsentrasi ekstrak Aglaophenia sp. dan aktivitas enzim selulase serta pektinase Fusarium

Tabel 2. Kandungan protein miselia Fusarium yang diperlakukan dengan ekstrak Aglaophenia sp.

\begin{tabular}{|c|c|c|c|}
\hline \multirow{2}{*}{ Konsentrasi ekstrak (ppm) } & \multicolumn{3}{|c|}{ Kandungan protein miselia $(\mu \mathrm{g} / \mathrm{g})$} \\
\hline & Metode Lowry & Metod & Bradford \\
\hline 0 & $208,71 \quad \mathrm{a}$ & 208,60 & a \\
\hline 63 & 205,37 a & 187,52 & a \\
\hline 125 & $195,76 \quad b$ & 170,24 & $\mathrm{a}$ \\
\hline 250 & $179,95 \quad c$ & 163,88 & a \\
\hline 500 & $159,88 \mathrm{~d}$ & 142,79 & $\mathrm{~b}$ \\
\hline 1000 & 127,79 e & 110,00 & $\mathrm{c}$ \\
\hline 2000 & $93,02 \mathrm{f}$ & 62,95 & $\mathrm{~d}$ \\
\hline
\end{tabular}

Angka-angka (rata-rata dari tiga ulangan) pada kolom yang sama yang diikuti oleh huruf yang sama tidak berbeda berdasarkan uji jarak berganda Duncan $(\mathrm{p}>0,05)$.

Pengaruh ekstrak Aglaophenia terhadap protein juga tampak pada gel SDS-PAGE seperti pada Gambar 2. Makin tinggi konsentrasi ekstrak makin rendah kandungan protein miselium. Protein pada konsentrasi ekstrak tinggi (1000 dan 2000 ppm) tampak lebih sedikit dibanding pada konsentrasi ekstrak yang lebih rendah. Hal ini ditunjukkan oleh tampilan pita-pita protein pada konsentrasi tinggi tersebut lebih tipis dibanding lainnya. Tertekannya pembentukan protein tersebut sangat berdampak pada rendahnya kemampuan jamur tumbuh dan menginfeksi sel inang.
Pengaruh Ekstrak Aglaophenia terhadap Persentase Busuk Batang Vanili. Perlakuan ekstrak kasar tidak berinteraksi dengan tanah asal inokulum terhadap persentase busuk batang vanili. Ekstrak kasar Aglaophenia sp. untuk semua konsentrasi yang diuji mampu menekan busuk batang dan berbeda secara nyata dibandingkan kontrol baik pada tanah endemik maupun pada tanah steril yang diinfestasi Fusarium (Tabel 3). Makin tinggi konsentrasi ekstrak diberikan, makin rendah persentase busuk batang yang terjadi pada kedua tanah sumber inokulum. Persentase busuk batang akibat 


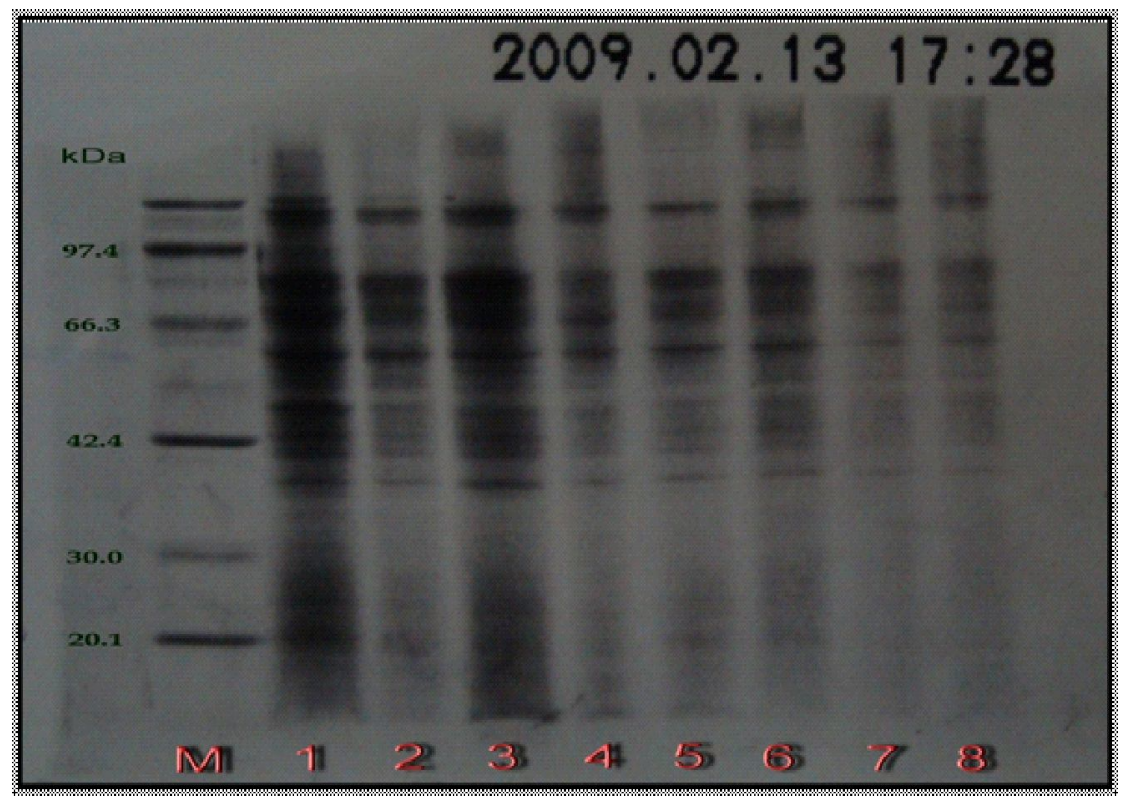

Gambar 2. Profil SDS-PAGE protein miselia Fusarium yang diperlakukan dengan ekstrak Aglaophenia sp. M: Marker; Line 1-8: pita protein pada konsentrasi ekstrak berturut-turut 0, 32, 63, 125, 250, 500, 1000, dan $2000 \mathrm{ppm}(\mathrm{w} / \mathrm{v})$

Tabel 3. Persentase busuk batang vanili pada tanah dengan dua jenis sumber inokulum yang diperlakukan dengan ekstrak Aglaophenia sp.

\begin{tabular}{ccc}
\hline \multirow{2}{*}{ Konsentrasi ekstrak $(\mathrm{ppm})$} & \multicolumn{2}{c}{ Busuk batang vanili (\%) } \\
\cline { 2 - 3 } & Tanah endemik & Tanah steril dengan inokulasi \\
\hline 0 & $80,00 \mathrm{a}$ & $96,67 \mathrm{a}$ \\
500 & $16,67 \mathrm{~b}$ & $23,33 \mathrm{~b}$ \\
1000 & $3,33 \mathrm{c}$ & $10,00 \mathrm{c}$ \\
2000 & $0,00 \mathrm{c}$ & $6,67 \mathrm{c}$ \\
4000 & $0,00 \mathrm{c}$ & $0,00 \mathrm{~d}$ \\
Mancozeb (2000) & $13,33 \mathrm{~b}$ & $20,00 \mathrm{~b}$ \\
\hline
\end{tabular}

Angka-angka (rata-rata dari tiga ulangan) pada kolom yang sama yang diikuti oleh huruf yang sama tidak berbeda berdasarkan uji jarak berganda Duncan $(p>0,05)$. Data dianalisis setelah ditransformasi arc sin akar $(\mathrm{x}+0,5)$.

perlakuan ekstrak 500 ppm (15\% pada tanah endemik dan $22,0 \%$ pada tanah steril yang diinokulasi patogen) sama dengan perlakuan mancozeb 2000 ppm dan bahkan lebih efektif dari fungisida tersebut untuk perlakuan ekstrak dengan konsentrasi yang lebih tinggi. Hal ini menunjukkan bahwa ekstrak Aglaophenia tersebut lebih efektif dibandingkan fungisida mancozeb dalam menekan patogen busuk batang.

Persentase busuk batang pada tanah steril secara nyata lebih tinggi dibandingkan pada tanah endemik (Tabel 3). Kemungkinan hal ini disebabkan oleh adanya keleluasaan perkembangan Fusarium tanpa adanya hambatan/kompetisi dari organisme tanah lainnya (seperti pada tanah endemik) sehingga serangannya terhadap vanili hanya dibatasi oleh konsentrasi ekstrak. Di samping itu, organisme lain dalam tanah yang mati akibat panas sterilisasi merupakan sumber makanan bagi Fusarium sehingga patogen dapat berkembang lebih cepat dan menyerang vanili lebih intensif dibandingkan pada tanah endemik yang penuh kompetisi. Berdasarkan pembiakan dengan metode cawan tuang, dalam tanah endemik ditemukan berbagai jenis mikroba dengan populasi yang tinggi (Tabel 4). Berbagai jamur dan bakteri yang ditemukan pada tanah endemik, di antaranya adalah jamur Penicillium sp. $\left(2 \times 10^{5} \mathrm{CFU} / \mathrm{g}\right.$ tanah) dan Streptomyces ( $3 \times 10^{5} \mathrm{CFU} / \mathrm{g}$ tanah) diketahui 
dapat mengeluarkan senyawa antimikroba. Senyawa tersebut dapat berpengaruh terhadap Fusarium dan mikroba lainnya dengan membatasi perkembangannya (Sudana, 1997; Dickinson, 2003). Selanjutnya Tombe $e t$ al. (2005) mengungkapkan bahwa Penicillium spp. dapat menghambat pertumbuhan Fusarium dalam pengujian di media buatan. Menurut Agrios (1989) dalam perkembangannya, patogen dalam tanah akan terhambat akibat adanya mikroba lain terutama yang bersifat antagonis. Selain berkompetisi terhadap nutrisi, mikroba antagonis sering menyebabkan spora patogen tidak dapat berkecambah (fungistatis). Hal ini terjadi

Tabel 4. Jenis dan populasi mikroba yang dijumpai pada tanah endemik sebelum perlakuan

\begin{tabular}{|c|c|c|c|}
\hline No. & Jen is/ciri mikroba & $\begin{array}{c}\text { Populasi } \\
\left(10^{5} \mathrm{CFU} / g \text { tanah }\right)\end{array}$ & Keterangan \\
\hline 1 & $\begin{array}{l}\text { Fusarium } \\
\text { oxysporum }\end{array}$ & 10 & $\begin{array}{l}\text { - koloni putih, dasar koloni ungu } \\
\text { - konidiofor pendek (jauh lebih pendek } \\
\text { dibanding F. solani: Matuo, } 1972 \text { ) }\end{array}$ \\
\hline 2 & Fusarium solani & 1 & $\begin{array}{l}\text { - koloni putih kekuningan } \\
\text { - dasar koloni pada media kekuningan }\end{array}$ \\
\hline 3 & $\begin{array}{l}\text { Penicillium sp. } \\
\text { (M oniliales) }\end{array}$ & 2 & $\begin{array}{l}\text { - koloni berwarna hijau, konidiofor } \\
\text { bersekat dan bercabang }\end{array}$ \\
\hline 4 & $\begin{array}{l}\text { Aspergillus niger } \\
\text { (M oniliales) }\end{array}$ & 1 & $\begin{array}{l}\text { - koloni warna hitam, ada sel kaki } \\
\text { (foot cell), konidiofor tidak bersekat }\end{array}$ \\
\hline 5 & $\begin{array}{l}\text { Aspergillus flavus } \\
\text { (M oniliales) }\end{array}$ & 1 & $\begin{array}{l}\text { - koloni coklat kehitaman, ada sel kaki } \\
\text { (foot cell), konid iofor tidak bersekat }\end{array}$ \\
\hline 6 & $\begin{array}{l}\text { Rhizopus sp. } \\
\text { (M ucorales) }\end{array}$ & 2 & $\begin{array}{l}\text { - koloni putih dengan sporangium } \\
\text { berwarna hitam, berstolon, sporangium } \\
\text { mengandung vesikel }\end{array}$ \\
\hline 7 & $\begin{array}{l}\text { B akteri koloni } \\
\text { kuning }\end{array}$ & 145 & $\begin{array}{l}\text { - bentuk koloni: bundar } \\
\text { - tepian koloni: licin } \\
\text { - elevasi koloni: cembung }\end{array}$ \\
\hline 8 & $\begin{array}{l}\text { B akteri koloni } \\
\text { bening }\end{array}$ & 2 & $\begin{array}{l}\text { - bentuk koloni: filiform } \\
\text { - tepian koloni: b erombak } \\
\text { - elevasi koloni: cembung }\end{array}$ \\
\hline 9 & B akteri koloni putih & 22 & $\begin{array}{l}\text { - bentuk koloni: bundar } \\
\text { - tepian koloni: licin } \\
\text { - elevasi koloni: cembung }\end{array}$ \\
\hline 10 & Strep tomyces & 3 & $\begin{array}{l}\text { - koloni kuning, berbenang-benang (bakteri } \\
\text { Gram positif: Dickinson, 2003) }\end{array}$ \\
\hline
\end{tabular}

Media kultur yang digunakan adalah PDA. Penentuan jumlah koloni dilakukan dengan metode cawan tu ang (Hadiuto mo, 1982). Data diperoleh dari rata-rata tiga u langan.

Tabel 5. Kerapatan inokulum Fusarium pada tanah dengan dua jenis sumber inokulum yang diperlakukan dengan ekstrak Aglaophenia sp.

\begin{tabular}{ccc}
\hline \multirow{2}{*}{ Konsentrasi ekstrak $(\mathrm{ppm})$} & \multicolumn{2}{c}{ Kerapatan inokulum $\left(\mathrm{x} 10^{5} \mathrm{CFU} / \mathrm{g}\right.$ tanah) } \\
\cline { 2 - 3 } & Tanah endemik & Tanah steril dengan inokulasi \\
\hline 0 & $30,67 \mathrm{a}$ & $46,67 \mathrm{a}$ \\
500 & $20,01 \mathrm{~b}$ & $27,12 \mathrm{~b}$ \\
1000 & $15,67 \mathrm{~b}$ & $23,67 \mathrm{~b}$ \\
2000 & $7,33 \mathrm{c}$ & $11,67 \mathrm{c}$ \\
4000 & $2,00 \mathrm{~d}$ & $6,33 \mathrm{~d}$ \\
\hline
\end{tabular}

Angka-angka (rata-rata dari tiga ulangan) pada kolom yang sama yang diikuti oleh huruf yang sama tidak berbeda berdasarkan uji jarak berganda Duncan $(p>0,05)$. Data dianalisis setelah ditransformasi $\log (\mathrm{x}+1)$. 
karena mikroba antagonis dapat mengeluarkan metabolit toksik yang menghambat perkecambahan bahkan melisis tabung kecambah.

\section{Pengaruh Ekstrak Aglaophenia terhadap Jumlah} Inokulum Fusarium. Keberadaan jumlah inokulum dalam media tanam vanili secara nyata tertekan oleh ekstrak Aglaophenia dibandingkan kontrol. Makin tinggi konsentrasi ekstrak, makin rendah jumlah inokulum dalam tanah (Tabel 5). Jumlah inokulum pada kontrol tanah endemik adalah $30,67 \times 10^{5} \mathrm{CFU} / \mathrm{g}$ tanah dan makin rendah jumlahnya seiring meningkatnya perlakuan konsentrasi ekstrak sampai hanya 2,00x $10^{5} \mathrm{CFU} / \mathrm{g}$ tanah pada konsentrasi $4000 \mathrm{ppm}$. Angka ini tidak berbeda nyata dengan perlakuan fungisida mancozeb pada konsentrasi anjuran 2000 ppm.

Jumlah inokulum Fusarium dalam tanah steril yang diinokulasi patogen tersebut lebih tinggi dibandingkan pada tanah endemik (Tabel 5). Hal ini menunjukkan adanya keleluasaan perkembangan inokulum Fusarium tanpa adanya pengaruh kompetisi mikroba lain seperti pada tanah endemik.

\section{SIMPULAN}

Aktivitas enzim ekstraseluler Fusarium dan kandungan proteinnya secara nyata menurun setelah diberi perlakuan konsentrasi ekstrak Aglaophenia yang meningkat. Penurunan aktivitas enzim patogen tersebut seiring dengan menurunnya persentase busuk batang pada tanaman vanili. Keefektivan ekstrak tersebut terhadap Fusarium lebih tinggi dibandingkan dengan mancozeb. Hal ini menunjukkan bahwa ekstrak hewan laut Aglaophenia sp. sangat efektif sebagai fungisida untuk mengendalikan Fusarium oxysporum penyebab busuk batang vanili.

\section{UCAPAN TERIMAKASIH}

Ucapan terima kasih penulis sampaikan kepada Bapak Sekar atas bantuannya mencari sampel hewan laut. Kepada pemerintah melalui DP2M Ditjen DIKTI kami sangat berterimakasih atas dana yang diberikan sehingga penelitian ini dapat berjalan. Akhirnya kepada semua pihak yang telah memberi bantuan penulis sampaikan pula terimakasih.

\section{DAFTAR PUSTAKA}

Agrios GN. 1989. Introduction to Plant Pathology. John Wiley and Sons. New York. 665p.
Bateman DF \& Basham HG. 1976. Degradation of plant cell walls and membranes by microbial enzymes. Pp. 456-468 In: Heitefuss R and Williams PH. Encyclopedia of plant physiology. SpringerVerlag, New York.

Bruhlmann F, Kim KS, Zimmerman W \& Fiechter A. 1994. Pectinolityc enzymes from Actinomycetes for the degumming of ramie bast fibers. Applied and Environmental Microbiology 60(6):21072112.

Clausen JS \& Reen F. 1996. Characterization of polygalacturonase from the brown rot fungus Postia placenta. Applied Microbiology and Biotechnol. 45:750-754.

deVries RP \& Visser J. 2001. Aspergillus enzymes involved in the degradation in plant cell wall polysaccharides. Microbiology and Molecular Biology Review 65:497-522.

Dickinson M. 2003. Molecular Plant Pathology. Bios Scientific Publishers, London. 244p.

Hadiutomo RS. 1982. Mikrobiologi dalam Praktek. Bagian Mikrobiologi, Institut Pertanian Bogor, Bogor.

Mahalingam RG, Wang \& Knap KH. 1999. Polygalacturonase and polygalacturonaseinhibitor protein: Gene and transcription in Glycine max-Heterodera glycines interaction. Molecular Plant Microbiology Interaction 12:490-498.

Ohazurike NC \& Arinze AE. 1999. Inhibitory effects of some host constituents on the post-harvest Sclerotium rot of varieties of cocoyam tubers. $J$. of Innovation in Life Sciences 4:12-19.

Onuh OM \& Ohazurike NC. 2008. Effects of culture ages on the production and activities of polygalacturonase and cellulose $(\mathrm{Cx})$ enzymes produced by Pythium aphanidermatum (EDSON FITZFAT.) isolated from soft stem rot disease of cowpea. J. of Science World 3(2):5-9.

Owen-Going TN, Beninger CW, Christie B, Sutton JC $\&$ Hall JC. 2004. Role of phenolic compounds in epidemics of Pythium root rot (Pythium aphanidermatum) of hydroponic pepper. Can. J. of Plant Pathol. 26(1):410-419.

Reignault P, Valette-Collet O \& Boccara M. 2008. The important of fungal pectinolityc enzymes in plant 
invasion, host adaptability and symptom type. Eur. J. Plant Pathol. 120:1-11.

Scott PT, Martin HL, Boreel SM, Wearing AH \& Maclean DJ. 2005. Molecular characterization, pthogenesis, and fungicide sensitivity of Pythium spp. from table beet (Beta vulgaris var. vulgaris) grown in the Lockyer Valley, Queensland. Australasian Plant Pathol.34(3):361-368.

Sudana IM. 1997. Metabolit sekunder baru dari Pseudomonas fluorescens efektif mengendalikan Ceratocystis paradoxa pada tanaman kelapa (Tidak diterbitkan). ITB, Bandung.

Sutton JC, Sopher CR, Owen-Going TN, Liu W, Grodzinski B, Hall JC \& Benchimol RL. 2006. Etiology and epidemiology of Pythium root rot in hydroponic crops: current knowledge and perspectives. Summa Phytopathol. 32(4):118130.
Tombe M, Sukamto, Zulhisnain \& Taufiq E. 2005. Budidaya vanili dengan menggunakan teknologi Bio-FOB. Balai Penelitian Tanaman Rempah dan Obat, Bogor. Perkembangan Teknologi TRO, XVII(1):31-40.

Ugwuanyi JO \& Obeta JAN. 1997. Some pectinolytic and cellulolytic enzyme activities of fungi causing rots of cocoyams. J. Sci. Food Agric. 73:432436.

Wei-Chen C, Huann-Ju H \& Tsung-Che TT. 1998. Purification and characterization of pectin liase from Pythium splendens infected cucumber fruits. Botanical Bulletin Academy 39:181-186.

Wu HS, Raza W, Liu DY, Wu CL, Mao ZS, Xu YC \& Shen QR. 2008 Allelopathic impact of artificially applied coumarin on Fusarium oxysporum f.sp. niveum. World J. Microbiol. Biotechnol. 24:1297-1304. 